Nezir AKYEŞILMEN

DOI : $10.14746 /$ ps.2020.1.5

Selcuk University, Turkey

https://orcid.org/0000-0001-8184-5280

Vanessa TINKER

Collegium Civitas, Warsaw

https://orcid.org/0000-0003-0955-4299

Mohammed ISHMEAL

Selcuk University, Turkey

https://orcid.org/0000-0003-1185-5074

\title{
TURKEY-US RELATIONS IN THE CONTEXT OF THE SYRIAN CONFLICT: FROM COOPERATION TO CONFRONTATION
}

\section{INTRODUCTION}

For over seven decades, Turkey and the U.S. have cooperated as strategic partners and allies in NATO. Turkey served as a crucial ally against the Soviet Union during the Cold War, in containing Iran and Iraq, stabilizing the Balkans in the 1990s, and in the prompting of the "East-West Energy Corridor."' Until recently, Turkey was regarded as a model for the Middle East and the Muslim world in demonstrating the compatibility between moderate Islam and Democracy (Aydıntaşbaş, Kirişçi, 2017: 1). Turkey is also popularly referred to as the bridge between the East and the West.

When Turkey became a republic in 1923 and adopted a western democratic form of governance in 1950, it became a strategic ally of NATO and United States. However, Turkey-US relations have not always been a smooth one, but rather they have historically shared incessant tensions. Zanotti expounds that "[T]heir strategic cooperation also has a history of complications. This is based largely on divergences in how the two countries' leaders have assessed their respective interests given different geographical positions, threat, perceptions, and roles in regional and global political and security architectures" (2013: 1). Despite these challenges, both countries have continued to proclaim their firm commitment in assuring the continuation of their strategic relationship.

In the case of Syria, Turkey and US initially shared the same policy objective and direction to oust Bashar al-Assad from power for a friendly administration which would serve both government interests for collective security and peace in the region. However, this initial consensus, as Barkey discusses, "was ultimately undermined by the length, severity, and endlessness of the unfolding conflict, as well as, by how each

${ }^{1}$ The East-West Energy Corridor refers to the Baku-Tbilisi-Ceyhan (BTC) oil pipeline and the Shah Deniz gas pipeline projects crossing Azerbaijan, Georgia and Turkey. 
government interpreted the other's policy actions" (2016: 26). The misperception that ensued against the backdrop of the aftermath of 15 th July coup d'état attempt in Turkey deepened the deep-seated chaotic relationship that existed between Turkey and US. It became uncertain whether these policy disagreements represented a temporary crisis resulting from underlying structural tensions, or a more drastic, if not dangerous, change in their bilateral relationship. Paradoxically, a new window of hope opened with the election of Donald Trump in the 2016 election, replacing the Obama administration. However, this initially optimism was short lived, and many in Ankara remain unsatisfied under Trump.

When attempting to understand how Turkey-U.S. relations ended up in this "undeclared crisis" in Syria, analysts have examined the topic from several different angles. Bennett for example provides a thorough examination on how the two countries interests and policies have converged and diverged over the years (Bennett, 2015). But more recently, many scholars have sought to understand the degree of damage in U.S.-Turkey relations in the arena of the Syrian conflict by focusing and debating on the 'substantial damage' resulting from a series of disagreements that has threatened the already waning relationship between U.S.-Turkey. Yegin and Selim for example, assert the recent events in Syria have contributed to the negative decline in the two allies' partnership (2016). However, scholars like Aydıntaşbaş and Kiriş̧̧i choose a more forward-looking approach, bypassing any historical analysis of the past U.S.-Turkey clashes. They focus on current dilemmas and questions facing both countries, playing out possible scenarios and providing alternative courses of action to restore and strengthen their cooperation (Aydıntaşbaş, Kirişçi, 2017: 1). Few analyses however provide a holistic understanding of the different dimensions and dynamics of the conflict between the two allies.

In terms of identifying the origins of the deterioration of U.S.-Turkey relations, there remains no agreement amongst analysts. When reviewing the literature on U.S.-Turkey relations, the most critical points attributed to the decline include: the U.S. invasion in Iraq 2003 (Türkmen, 2010), the 2011 Arab Spring uprising (Tanır, 2011: 71-78), the siege of Kobani in 2014 (Tanış, 2016), immediately following the 15 July 2016 coup attempt in Turkey (Aydıntaşbaş, Kirişçi, 2017: 1), Turkey's acquisition of S-400 Long Range Air and Missile Defense System from Russia and the subsequent suspension of Turkey by U.S. from the F-35 stealth fighter jet program (Aljazeera, 2019a), or more recently the maximalist resolve of Turkey to push mainly Kurdish Yekineyên Parastina Gel 'Peoples Defence Unit'-YPG and its perceived sister wing in Southern Turkey Partiya Karkerên Kurdistane 'Kurdistan Workers Party'-PKK beyond the 32-kilometer stretch of territory from the Euphrates River to the Syria-Turkey-Iraq border (Stein, 2019). Rarely do scholars pay attention to the deeper historical, cultural, and structural roots of the conflict. Instead they provide a superficial understanding of the current diplomatic crisis that ensued since 2014 between the U.S. and Turkey. ${ }^{2}$

${ }^{2}$ By crisis, we refer here to non-violent crisis since Turkey and the U.S. fall in this category according to the 2016 conflict barometer. Non-violent crisis is described by The Heidelberg Institute for International Conflict Research (HIIK) as one actor threatening to use violence on another such as violence against objects without imposing any harm on persons, the rejection of arms surrender, facing weapon systems against each other and sanctions. 
Thus, this article seeks to address some of these shortcomings and shed new insight into the tensions threatening the long outstanding cooperation that has kept U.S.-Turkey relations glued together in the midst of disagreement. This paper seeks to answer questions on how Turkey and the U.S. ended up in this critical crisis in the context of Syria. Furthermore, it discusses the sustainability of their relationship, in light of the current developments of multi-polarism in the world of politics, and whether there is any possibility for convergence, cooperation, and restoration of their relationship. Additionally, this article proposes channels and platforms available in a bid to improve U.S.-Turkey relations. Finally, the paper concludes by examining the germane factors underpinning U.S.-Turkey relation as strategic partners necessary for peace in the region and the world at large.

To succeed with this aim, the authors critically analyze the relationship between Turkey and the U.S. in light of the Syrian crisis by drawing from secondary sources - both in English and Turkish, and analyzing them with tools of conflict analysis. The analysis then proceeds by tracing the historical background of the conflict, identifying a number of root causes of the conflict that have placed a tremendous strain on their relationship, highlighting positions, interests and needs in both countries in order to understand where they converge or diverge, and then presents a number of future scenarios and policy recommendations to restore their relationship and trust, possibly leading to new fruitful ways of cooperation.

\section{THEORETICAL FRAMEWORK: CONFLICT ANALYSIS}

Before proceeding with our analysis, it is important to briefly explain what we mean by conflict and conflict analysis, and how we intend to employ them here in this article. The term conflict has been defined in various ways, depending on different philosophical assumptions, type, level, and intensity of a conflict. In our analysis, we focus specifically on political conflicts. For this reason, we understand conflict as "the clashing of interests (positional differences) on national values of some duration and magnitude between at least two parties (organized groups, states, organizations) that are determined to pursue their interests and win their case" (HIIK, 2003: 2). As this definition implies, there are at least two conflicting parties, each interdependent of each other, however perceiving the other side as an obstacle in reaching their goals.

To understand the different aspects of political conflicts, we utilize conflict analysis tools that refer to, "the systematic study of the profile, causes, actors, and dynamics of conflict" (Safeworld, 2016: 1). For the purpose of this article, we have developed a framework drawn from several conflict analysis tools, enabling us to exhume the deep-rooted causes of the current diplomatic crisis between Turkey and the U.S. This analysis does not claim to provide an exhaustive look at the conflict, or provide any definitive answers, since conflict dynamics are too complex and volatile to understand precisely. However, it will enable us to organize the information from different worldview perspectives - namely that of Turkey and the U.S., to gain a critical grasp of the different dimensions of the conflict, and from these findings, present a number of likely scenarios for the future, and policy recommendations on how to proceed to reconcile their partnership. 
Equally important is the fact that many different conflict analysis frameworks exist, neither necessarily more superior than the other, rather each is selected to focus on certain aspects of a conflict (Safeworld, 2016: 12). There are however four common features that typically exist among them: the conflict profile (e.g. the historical background, context, emerging issues), causes of conflict (e.g. historical, political, cultural, social and geographical), environmental analysis (e.g. internal, regional, and global developments influencing the escalation of a conflict) actors analysis (positions, interests, needs, and capacities), and conflict transformation strategies (windows of opportunity, scenarios, and policy recommendations) (Safeworld, 2016: 12). We have drawn from a number of conflict analysis tools and modified them for the needs and purpose of our analysis as illustrated in Table 1 (Bağc1, 2014: 7).

\section{Conflict Analysis Framework}

Table 1

\begin{tabular}{|c|c|}
\hline 1. Conflict Profile & $\begin{array}{l}\text { a) Historical background of the conflict; } \\
\text { b) Principle stages of the conflict; } \\
\text { c) Emergent political, economic, ecological and social issues }\end{array}$ \\
\hline 2. Causes of the Conflict & $\begin{array}{l}\text { a) Historical (historical relationships between the parties); } \\
\text { b) Political (political developments, conflicting political interests and demands, } \\
\text { political regimes, democratization and human rights etc.); } \\
\text { c) Economical (the level of domestic and international trade, economic interests, } \\
\text { per capita income, distribution, trade and resources); } \\
\text { d) Social and cultural (structure of the society, demography, education, equality } \\
\text { and discriminations, identity, religion, ideology etc.); } \\
\text { e) Geographical (effects of geography, neighbors, adjacent conflict zones etc.) } \\
\text { causes are assessed one by one }\end{array}$ \\
\hline 3. Environmental Analysis & $\begin{array}{l}\text { a) The impact of other internal, regional and global developments on the con- } \\
\text { flict's escalation; }\end{array}$ \\
\hline 4. Actors Analysis & $\begin{array}{l}\text { a) Primary actors involved in the conflict; } \\
\text { b) Their positions, interests, needs and capacities; }\end{array}$ \\
\hline 5. Conflict Transformation & $\begin{array}{l}\text { a) Windows of opportunity; } \\
\text { b) Possible scenarios; } \\
\text { c) Policy Recommendations on ways to move forward }\end{array}$ \\
\hline
\end{tabular}

Sources: Various sources including Çatışma Analizi: hak-Temelli Stratejik Barış Modeli, by Nezir Akyeşilmen in Ertan Efegil and Esra Pakin Albayrakoğlu (eds.), Türkiye'nin Yakın Havzasındaki Devlet İçi Çatışmaların Analizleri, Gündoğan Yayınları, İstanbul 2015 and N. Akyesilmen, Barışı Konuşmak: Teori ve Pratikte Çatışma Yönetimi, ODTÜ yayınları, Ankara 2014 and N. Akyesilmen, V. Tinker, Conflict Analysis: A Rights-Based Peace Model, in: N. Akyeşilmen, Ö. Afşar, The Possibilities of Peace in Syria, Orion Yayınevi, Ankara 2016.

For the remainder of the article, we will use this conflict analysis framework to examine the conflict between Turkey and the U.S. in Syria. We now proceed in the next section by looking at the conflict profile.

\section{CONFLICT PROFILE: BACKGROUND ANALYSIS OF THE CONFLICT IN SYRIA}

To understand the context of the current conflict between Turkey and the U.S. in Syria, we begin with an analysis of the background events that led to the eventual involvement of both countries in the Syrian war, tracing back to when and how their 
policies converged, diverged, and later deteriorated into the state of diplomatic crisis they find themselves in today. We do so according to three different but interlinked stages: 1) the period of convergence; 2) the period of divergence; and 3) the period of diplomatic crisis.

\section{Stage 1. Period of Convergence in Syria 2011-2012}

Initially when anti-government protests erupted in Tunisia in 2010, and then in Egypt, Libya and Syria, known as the Arab Spring, optimists believed the Middle East was on the verge of a drastic democratic transformation (Schanzer, Tahiroglu, 2016). This optimism at first seemed to be confirmed after the fall of President Zine El Abidine Ben Ali in Tunisia, Hosni Mubarak in Egypt and later Muammar Mohammed Abu Minyar Gaddafi in Libya. Many political analysts such as Muasher and Bubnova (2012), assumed the same fate would befall on Bashar al-Assad's Syrian regime that was likely to oust him from power through resignation. However, as the world has witnessed, this has not been the case.

When civil unrest broke out in Syria, many members within the international community sought to support the opposition against the Assad regime, by passing a United Nations security Council (UNSC) resolution that would have allowed for the arming of the opposition and creating a no-fly zone. In 2011, and then again in 2012, both Russia and China obstructed the possibility of any UNSC resolution from passing. Nevertheless, Western powers have continued to back and arm selected opposition groups, leading to the massive proxy war the world continues to witness today in Syria (Demir, 2012: 569).

From the onset of the Syrian War, Turkey and the U.S. policy goals converged: to remove the Assad regime. Initially, Turkey and the U.S. both called for Assad to make reforms to avoid massive protests as was the case in Arab Spring. Both countries sought diplomatic solutions to push Assad towards a peaceful resolution. Turkey in particular overestimated its influence over Assad. Throughout 2011, former Prime Minister, now President Recep Tayyip Erdoğan, and former Foreign Minister Ahmet Davutoğlu sought for a peaceful transformation in Syria (Abramowitz, Edelman, 2013: 24; Altunışık, 2016: 40; Albright, Hadley, 2012: 40). When Turkey saw no hope for change, Turkey-Syria relations rapidly deteriorated (Çağlar, 2012: 39-52). According to Tanır and Doster, "Ankara, at first, tried hard to convince Assad to take the path of political reform with no avail. It became clear following Davutoğlu's six-and-a-halfhour meeting with president Bashar al-Assad in early August (2011) that Assad was not going to listen to Turkish advice" (Tanır, 2012: 71-78; Doster, 2013: 72-79).

When Assad continued to crack down on protestors and failed to implement the reforms, both Turkey and the U.S. called for Assad to step down in 2011. Turkey expected the U.S. to back this demand with a ready willingness to strike with missiles. However, it was only after Assad acknowledged possessing chemical weapons that Obama issued a "red line" warning, threating to use military strikes on Assad's regime if the weapons were used on civilians. Therefore, as evidence emerged that Assad was using chemical weapons on civilians in Homs (Melhem, 2017), Turkey assumed the U.S. would follow through with its threat. To Turkey's dismay, the Obama administra- 
tion wavered, stating no action would be taken until there was congressional approval. It was then that Turkey began losing faith in the U.S. as a reliable ally ready to facilitate her interest in the Syrian War.

Soon after, Turkey reassessed its strategies in Syria, and likewise with the U.S., and opted to give full support to opposition groups and to cut all ties and communication channels with the Assad regime. "After the failure of a UN Security Council resolution and a range of initiatives that demanded President Assad to delegate his authority to the Syrian vice president and establish a national unity government," Albright and Hadley discuss how Ankara began intensifying its anti-Assad rhetoric concerning the humanitarian abuses and hinted the possibility of arming the Free Syrian Army (FSA) (2012: 40-41).

By late summer of 2011, Ankara attempted to organize the opposition against the Syrian regime, leading to the creation of the Syrian National Council and the Free Syrian Army, while at the same time, searching for the creation of a broad international coalition to respond to the Syrian crisis. During this stage, Turkey actively supported the opposition and embarked on the policy regime change. Turkey harbored opposition leaders and organized the Free Syrian Army (FSA) in 2011 (Altunışık, 2016: 40-41). By mid-2012, Turkey, together with its Western allies, provided training and armed the Free Syrian Army which later resulted with reciprocal shelling across the border (Abramowitz, Edelman, 2013: 20-24). Yet the U.S. continued prioritizing stability and avoided any direct military intervention which left Turkey largely isolated, frustrated and disappointed (Zanotti, 2013: 4).

Despite Assad's gross display of human rights violations, use of chemical weapons on innocent civilians, the U.S. administration, along with NATO and its Western allies failed to intervene militarily. Turkey was disappointed for their inaction in removing Assad. Likewise, the U.S. doubted Turkey's commitment to fight against ISIS due to rising claims that Turkey was not only being soft on ISIS, but also providing them with military and logistic assistance (Zanotti, 2013: 17). These developments led to the second stage in the U.S.-Turkey relations in Syria - divergence.

\section{Stage 2: The Period of Divergence 2012-2015}

The period of divergence was marked by indifference, misperception, frustrations, disappointment and betrayal which in turn shaped Turkey and U.S. interest in the Syrian conflict. In fact, it was the beginning of foreign policy change in relation to the Syrian conflict that muddied U.S.-Turkey strategic relations. This change suddenly drove Turkey to seek the S-400 defense system from Russia. The policy change towards addressing the "Syrian Question" was motivated by several factors: the prolonged nature of the conflict, the catastrophic nature of the violence, the entrenched divisional cracks, and the weakness of the opposition coupled with the extreme radicalization of the opposition forces inside Syria, all of which changed the dynamics of the Syrian conflict. In 2013, an al-Qaeda-linked faction Al-Nusra Front, and then later ISIS emerged as important actors in the opposition, fully armed, financed and motivated to fight against the Assad regime. Fighting broke out between pro-regime actors such as Iran and Hezbollah against the opposition forces of Al-Nusra Front and ISIS. The lat- 
ter two emerged as powerful actors after gaining control over substantial territory in Syria. It should be noted that war also broke out between ISIS and Kurdish YPG militia. Meanwhile, international coalitions, namely the U.S. and the UK decided to limit their support for rebels in the North. Thus, Turkey was left alone partly in its support of the moderate opposition (Altunışı, 2016: 43).

The prolonged nature of the Syrian crisis, along with the U.S.'s lack of contribution and adopted policy of "leading from behind," left Turkey with tremendous financial, human, and diplomatic costs. The U.S.'s expressed reluctance to provide greater backing for the Syrian opposition, left Turkey to question the depth of U.S.-Turkey cooperation (Ahmad, 2015: 17; Altunışık, 2016: 41). This was particularly the case when Turkey wanted to directly intervene in Syria, including land operations, but the U.S. declined. The U.S. decision was based on two reasons: first, ISIS and other radical groups who were controlling a wide range of territory, and second, the opposition groups were too fragmented (Pirinççi, et all, 2014: 18).

During this stage, Turkey took serious measures to block its border against foreign fighters as a part of its strategy to fight against ISIS. The protective measures taken by the government of Turkey included: (1) preventing potential foreign fighters from entering Turkey, (2) preventing those who enter Turkey from traveling to Syria, and (3) curbing illicit oil smuggling used to finance jihadist activities. According to a Turkish government source, these measures included: enforcing a no-entry list (created in 2011) for individuals suspected of traveling to join radical groups in Syria; establishing "risk analysis units" in April 2014 for the detection of travelers' possible intent to join Syrian extremist organizations; enhanced security at the Syrian border, including the general closure of most border gates, the deployment of additional army units and special operations battalions to border areas, and the creation of physical impediments to counter illegal crossings and smuggling; employing and enhancing "forceful and ongoing measures" (dating from 2012) to curb oil smuggling, including the capture of oil stores and destruction of illegal pipelines (Zanotti, 2013: 7-8).

Meanwhile, with the fall of Raqqa in August 2014, the self-proclaimed caliphate by ISIS, and the attack of Kobane in September 2014, the U.S. decided to support the Kurdish Democratic Union Party (PYD) and its military wing, the YPG particularly Kurdish (Yekîneyên Parastina Gel, peoples protection Unit) via air strikes (Altunışık, 2016: 43). From the onset, Turkey has not hidden its displeasure in America's support for the Syrian Kurdish PYD and its YPG (Yekîneyên Parastina Gel) militia forces known as Peoples protection or Defense Unit (Barkey, 2016: 28-29). Turkey considers "both YPG and PKK as terrorist whereas United States only designates PKK to be terrorist not YPG" (Delay, 2017). Additionally, Russia and Iran became directly involved in Syria in the summer of 2015, due to possibility of regime change in Damascus (Altunışık, 2016: 43).

\section{Stage 3: The Period of Confrontation and Diplomatic Crisis 2015 to the Present}

Throughout stage three, the U.S. has continued to fully support the YPG, despite Turkey's protest. Turkey has also militarily intervened in Syria in 2016 on behalf of 
FSA. The aims were to remove ISIS from its borders, prevent Kurds uniting the Cantons and to persuade the U.S. to launch Raqqa operations together, not with the YPG and its militia. Being disappointed with the Obama Administration's Syrian policy, Turkey nurtured new hopes with the Trump administration. However, the decisionmakers of Turkey have been disappointed once more when the Trump administration decided to continue supporting and recapture Raqqa with YPG. It is not an exaggeration to claim that this is one of the most serious crises in the history of U.S.-Turkey relations in the last 70 years.

As a result of these developments in the Syrian crisis and breakdown of U.S.Turkey relations, the government of Turkey launched three initiatives.

First, the government tried to convince the US that non-YPG forces should fight against ISIL at the Menbic-Jarablus front, the only segment of the Turkish-Syrian border that has not been controlled by the PYD. The second initiative sought to improve relations with Iran. Tehran's own concerns about the developments in Syria has opened up a space for developing a common understanding between the two countries. As President Rouhani's visit demonstrated, they are not there yet, although it has been shown that they have the resolve to work towards bridging their differences. Finally, Turkey has agreed with the EU, to manage the refugee crisis together (Altunışı, 2016: 43).

The U.S. support for PYG remains the central issue of contention of the undeclared crisis between Turkey and the U.S. Turkey came to understand that it could no longer trust the U.S. in ensuring its safety. Thus, after the failed coup d'état against the AK party in 15 July 2016, Turkey took several steps to improve its relations with Russia. The good relationship built over the period offered Turkey an alternative to acquire Russia's weapons. Turkey subsequently bought the sophisticated S-400 defense system which was delivered to Turkey 12 July 2019. Turkey considered their acquisition of this war defense system worth 2 billion dollars as a "necessity" for the survival of the Turkish state and to safeguard peace for its citizen. Despite the U.S. being against the purchase of this defense weapon, Turkey has defended its decision by pointing out that the U.S. failed to offer them an "American alternative" (Lister, 2019). Turkey maintains that it was the left with no alternative other then acquiring the Russian monster S-400. In retaliation, the U.S. implemented a new policy which has made it possible for Turkey to be withdrawn from the F-35 jet program.

After briefly analyzing the background of events that led to the eventual involvement of Turkey and the U.S. in the Syrian war, and identifying the points they converged, diverged and faced confrontation that has led to their current diplomatic crisis, the next section adopts a conflict analysis framework to identify some of the root causes that underpin the current conflict. Until now, background analyses in literature, have only provided a superficial understanding of both actors' positions. On the surface, the positions of both actors appeared non-negotiable, but by digging beneath the surface and looking at the root causes it is possible to unearth their interests and needs that can be traced back to the distant past and now play out into the current conflict. The complexities ingrained in this "friend-foe" (FF) relations with changing parallel and converging interest across time is well addressed. In fact, the current agreement between the U.S. and Turkey on the creation of a "safe zone" is an obvious example of how salient and complex U.S.-Turkey relations can be (Aljazeera, 2019b). 


\section{CAUSES OF THE CONFLICT}

One of the significant components of conflict analysis is to identify the root causes of a conflict and, in turn removing or mitigating them to resolve and/or transform the conflict. Thus, the following topics in this section discus and evaluate a myriad of factors such as the historical, strategic, political, and economic underpinnings of the friend-foe relations within the Syrian context (Akyesilmen, 2014: 22-31).

\section{Historical Causes}

Although Turkey and the U.S. have been strategic allies since the very beginning of the Cold War, they have faced several crises that have injured their mutual trust and interest. Among the most significant was the U.S. support for Iraqi Kurds during the 2003 Iraq invasion. The U.S. invasion in Iraq in particular impacted Turkey in 4 ways: 1) it increased sectarian violence and the fragmentation of the central government's control over the country; 2) increased Iranian influence; 3) Iraq Kurd's became driven for autonomy along Turkey's southern border posing or perceived as a threat to Turkish security with separatist pressures increased in Iraq threatening Turkey's territorial integrity; and 4) it increased drastically the violence by the PKK (Larrabee, 2010). And despite acknowledging the PKK as a terrorist organization, the U.S. refused to assist Turkey in going after them in a safe haven situated in Northern Iraq, with the U.S. stating they did not want to detract troops from Baghdad. The U.S. refusal led to heightened anti-Americanism in domestic arena of politics in Turkey.

For the U.S., the last straw that instigated a crucial breaking point in the U.S.Turkey strategic relation was the historical decision taken by the Parliament of Turkey on 1 March 2003 that refused the U.S. army to operate from Turkish bases and ports in the event of war in Iraq, calling into question the relevance of the existing "strategic partnership" (TEPAV, n.a.: 1; Kirdar, 2012: 1). Indeed, the U.S. was shocked, since it assumed with the AKP's majority, they would receive support. Turkey meanwhile assumed it had considerable leverage and bargaining power to make economic and political demands, of which the US found unacceptable. Consequently, the negative vote deprived Turkey of any post-conflict reconstruction efforts in Iraq and of carving out any niche of influence in the process of occupation.

\section{Strategic Causes}

The primary U.S. national interest in Syria is to remove ISIS and other terrorist organizations. Unlike the U.S., Turkey prefers to back and support the Free Syrian Army (FSA) forces. The U.S. does not trust their effectiveness, and instead believes that its alliance with the YPG will safeguard their long-term interests in Syria. By failing to back the YPG, the U.S. sees the alternative as a far greater danger. Without any of its forces in Syria, the U.S. runs the risk of allowing the formation of additional safe havens for radicalism and leaving a power vacuum for undesired powers 
such as Iran and Hezbollah, Sunni Islamists such as the Syrian Muslim Brotherhood, or more extreme groups, to gain a powerful stronghold in Syria (Abramowitz, Edelman, 2013: 19).

U.S. interests in Syria are directly linked to those in Iraq. According to Ahmad, the "U.S administration is focusing its strategy in Syria to alleviate terrorism threats and advance U.S. goals for an exit strategy in Iraq (2015: 15). Both of the U.S. strategic concerns in Syria and Iraq, however, are perceived of as a threat to Turkey's security. Openly Turkey had declared its dissatisfaction with the U.S.'s strategy, viewing their support of the YPG a direct threat to their national interest and territorial integrity with the emergence of a Kurdish entity in Northern Syria (Barkey, 2016: 32). Turkey views U.S. backing of YPG as a direct violation of their bilateral relations as well as going against the backing of a NATO ally. And in terms of Iraq, although Turkey has improved relations with the Kurdistan Regional Government, when it comes to sovereignty issues, the U.S. has tended to side with Baghdad rather than Ankara (Barkey, 2016: 32).

\section{Political Causes}

Instability in Syria has affected the domestic politics of Turkey due to refugees, ethnic, nationalism and religious sectarianism. To counter some of these undesired spillover effects, Turkey has tried at times to play it safe so as to not trigger a backlash internally or externally of its borders. The U.S. has interpreted Turkey's cautious stance as not fully supporting the fight against radicalism of groups, such as Al-Nusra and Ahrar-Alsham. Moreover, Turkey's recent cooperation with Russia has further added to the U.S. mistrust. Some of the primary political problems that led to the distrust between the two actors include:

Possible Turkish support or permissiveness regarding the use of Turkish territory for the supply and transit of Syrian jihadists and foreign fighters opposing the regime of Syrian President Bashar al Asad; General Abdel Fattah al Sisi's ousting of Egypt's elected president Muhammad Morsi (a Muslim Brotherhood figure) in 2013 and his subsequent steps as Egypt's new ruler to weaken the Muslim Brotherhood; Turkey's political support for Hamas, reported harboring of Hamas operational leaders, and regular denunciations of Israel, which are points of contention with some Members of Congress; U.S. and international material support since late 2014 for the Syrian Kurdish group PYD (Democratic Union of Syria) to help it defend territory against the Islamic State organization (also known as ISIL or ISIS) (Zanotti, 2013: 4).

In addition, there is a strain on bilateral relations with the Syrian Kurdish entity (Abramowitz, Edelman, 2013: 27), the emergence of radical groups, sectarian affinities, and Syrian power struggle (Zanotti, 2013: 29-30). The U.S. views the Rojava ${ }^{3}$ corridor as an important route for energy security. Yet Kurds consider it as a passageway for Kurdistan to reach the Sea.

\footnotetext{
${ }^{3}$ The Kurdish name fort the Northern Syria meaning Western (Kurdistan).
} 


\section{Geographical and Economic Causes}

Geographical causes are strongly interconnected with all the reasons mentioned above. Turkey feels under siege by Kurds in the South that geographically would cut Turkey-Arab ties and pave the way for Kurds to reach the sea which is vital for the safety and survival a possible Kurdish state in the future.

With regards to economic causes, Syria is an important trade gateway to Turkey. Turkey considers Syria as "both a recipient of and conduit for Turkish trade with the Arab Middle East. This is because the AKP's domestic popularity stems in part from the fact that Turkey's GDP has tripled between 2002 and 2010, largely because of a similar increase in exports" (Albright, Hadley, 2012: 26).

\section{Environmental Analysis: Dynamics Escalating the Conflict}

Environmental analysis focuses on the impact of domestic, regional and international developments on the parties of the conflict. An example of domestic and regional developments includes the ending of the Kurdish peace process in 2015 in Turkey and the impact of regional actors such as Iran, Saudi Arabia, Qatar, even European Union and global powers such Russia and China.

In the first instance, the Kurdish question has remained a domestic and regional source of tension that has escalated the Syrian conflict leading to diplomatic confusion between Turkey and the U.S. The breakdown of the Kurdish peace process in Turkey in 2015, led Turkey to revise its Syrian policy (Aydıntaşbaş, Kirişçi, 2017: 10). The PYD's capture of Kobane further escalated Turkey's security concerns. Barkey asserts that Syria has become a domestic political question for Turkey for two reasons. One is due to Kurdish question and the other is Turkey's harboring of the Sunni opposition that has raised concerns among Alewies in Turkey (2016: 30). Another source of contention has been the massive flood of refugees from Syria that has heightened internal tensions in Turkey in recent years. Altunışık highlights how:

Turkey's foreign policy has been in a significant predicament in recent years and the Syrian crisis has been the main source of it. The developments in Syria have affected Turkey at two levels. First, there has been a plethora of problems spilling over to Turkey from Syria, including security threats, the refugee crisis and the worsening of the Kurdish problem in Turkey. Second, Turkey's position in Syria has led to a deterioration of Turkey's relations with several countries, particularly Russia and Iran, as well as to an estrangement from its Western allies (2016: 39).

For example, the downing of Russian military jet in November 2015, followed by Russian retaliation of economic sanctions, created a misperception and misconception of an unrepairable damage of diplomatic relations between Russian and Turkey.

However, the coup incident on 15th July gave Russia an opportunity to change the diplomatic dynamics as U.S. and NATO allies failed to manage the aftershocks of the unfortunate military coup d'état attempt which sought to subvert democratic government rule. The Russian president Vladimir Putin and Moscow not only provided Ankara a solace, but also a green light to advance her Operation Olive Branch, 
deescalating the imminent conflict among their forces in the north. Turkey then took advantage of this opportunity to capture Afrin (Çağaptay, 2018). On the other hand, Assad also had the leverage to takeover East Ghouta and subdue the rebels. More recently, the renewed relationship between Turkey, Russia and Iran has changed the pattern of diplomatic relations in the context of Syrian conflict denting the strategic partnership between U.S. and Turkey (Wintour, 2018). These intervention and jostling for control by the regional and global powers in Syria deepened the woes of U.S.-Turkey relations. Obviously, regional actors such as Iran and Hezbollah, and later Russia's entry into the Syrian war rather widened the gap between U.S. and Turkey in their relations (Abramowitz, Edelman, 2013: 19). In this situation of uncertainty, fear of losing control of the Syrian crisis, and search for dependable allies and partners in dealing with the Syrian regime, the U.S. choice responsively became the Kurdish militia as allies designated as PYD including its affiliates. Unfortunately, the choice of the U.S. worsened the strategic partnership with Turkey as allies despite the current agreement on the establishment of safe zone. Based on the difficulties in implementing the agreement, it is evident that Turkey is still not satisfied, as her backed forces are operationally limited by U.S restrictions (Hacaoğlu, 2019).

The Syrian crisis also deteriorated relationships between Turkey and the European Union (EU). Particularly, the end of Kurdish Peace Process in Turkey, Turkey's unilateral intervention in Rojava, refugee crisis and emergence of radical groups in Syria, in short the process so called Arab Spring. Dinçer and Kutlay also join this idea by arguing that both Turkey and the EU had opportunity to establish democratic regimes in the region. And such cooperation would also lead to improve their mutual relationships. However, this opportunity turns into a threat due to differences in their interests and approaches regarding the Arab spring. “... the Arab Spring has opened a window of opportunity not just to create stability and democracy in one of the most unstable regions of the world, but also for revitalizing Turkey-EU relations. ...From a practical perspective, however, transforming the window of opportunity into policy output is linked to the policy leadership of the sides involved to undergo a paradigm shift in their approach to the region and toward one another" (Dinçer ve Kutlay, 2013: 418).

\section{ACTORS ANALYSIS: WHO WANTS WHAT?}

In this section, we are going to discuss the interests, positions and demands of Turkey and the U.S., identifying and then evaluating where and why they diverge and converge.

Turkey's positions, interests and needs are several, and at times contradictory. When civil unrest began in Syria, Ahmad argues "Turkey had three options: a) backing civilian opposition in addition to encouraging peaceful means; b) supporting military opposition with its own military capacity; and c) support military opposition with NATO assurance" (2015: 14). He critically questions why Turkey dropped the first and third options and went for the second option instead (Ahmad, 2015: 14). Turkey is also being criticized for underestimating the Assad regime and overestimating the Western willingness to topple down the regime (Ahmad, 2015: 15). 
Turkey's primary goals and interests in Syria include: regional ambitions, preventing the emergence of a Kurdish entity in the Northern Syria. political and economic stability. In this regard Abramowitz and Edelman claim that Turkey has multiple interests in the region, some of them incompatible within the chaotic situation in Syria. The primary goal is to restore stability across its borders to control the refugee problem and prevent the spill over of the Kurdish question from Rojava to its own country. Turkey has also tried to keep Syria as a trade route to the Middle East as well as transform the crisis into an opportunity to establish Turkey's regional hegemony (Abramowitz, Edelman, 2013: 21-25).

Unlike Turkey, the underlying interests of the U.S. are: "safeguarding its access to cheap oil, stabilizing [Syria and] Iraq, eliminating terrorism and keeping Israel secure" (Liu, Taylor, 2016: ix). In order to achieve these political objectives the U.S. supports and works with PYD and its affiliates (Ahmad, 2015: 16; Barkey, 2016: 25-36).

Regarding their different interests, Liu and Taylor put forward that "Turkey and the United States have common strategic interests such as ensuring stability in the Middle East, creating a prosperous and secure [Syria and] Iraq, countering terrorism and Islamic fundamentalism, achieving regional security in Afghanistan, maintaining strong economies, safeguarding the flow of oil and natural gas and promoting democracy and tolerance" (Liu, Taylor, 2016: vi). Furthermore, they share strategic interest to remove Assad's regime but they have different methods for this (Türkmen, 2010: 6).

However, there are many points of confrontation: [T] he more recent burgeoning U.S. alliance with Syrian Kurds; U.S. frustrations with what the White House once described as rising authoritarianism in Turkey; Ankara's demand for the extradition of U.S.-based cleric Fethullah Gülen, labeled by Ankara as the mastermind behind the failed coup-attempt in July 2016; and suspicions of prior U.S. knowledge of the coup. Acrimony grew on both sides (Aydıntaşbaş, Kirişçi, 2017: 2).

Indeed, it is not farfetched to posit that Turkey's increasing closer ties with Iran and Russia threaten U.S interest, since both are considered to be adversarial states in the region, competing against U.S for power and control. Moreover, the S-400 crisis caused an excruciating injury in U.S.-Turkey relations, with the U.S. still lacking any solution. The agreement on the safe zone along Turkey's boarder between Turkey and U.S. surreptitiously has simmered tensions in the area between U.S and Turkey. Contrary to Ankara's expectation, the U.S. reportedly agreed to 125 kilometers ( 78 miles), 15 kilometers deep, away from the Syrian towns of Tal Abyad and Ras al-Ayn, where both actors are supposed to occupy. However, extensive military activities are restricted, interestingly, the agreement allows civilians to occupy the area rather than Turkey's military forces. In effect, Turkey has about 10 brigades in the area to counter YPG's 1500 estimated forces along the Euphrates river and Iraqi border. Turkey's air power capability is also restricted to a mere surveillance which many scholars and officials in Ankara think is a grand scheme to halt Turkey's ambition of purging the Kurdish threat and safeguard its sovereignty and security. In sum, the agreement is a diplomatic powder keg which could blow up in no time later into a military confrontation between Turkey and Syria and the YPG on one hand, and on the other hand diplomatic row between U.S and Turkey. The actors' demands, interests, positions and policies in the context of Syria as seen above are sometimes cooperative but much more conflictual- 
chaotic relations. Harmonizing these different tendencies is hard but not impossible, because both countries have experiences and deep diplomatic relations for resolving political conflicts.

\section{PROSPECTS FOR THE FUTURE}

As this analysis has demonstrated, both countries for the foreseeable future will continue to need each other to achieve their regional and global objectives. However, as Ahmad correctly points out "both U.S. and Turkey need to decide how much they need each other" (2015: 16). What remains clear, is the U.S. needs Turkey, serving as a bridge to the Middle East, the Caucasus and Eurasia. Furthermore, it is a fact that $70 \%$ of US military supplies for Iraq and Afghanistan go through Turkey's military bases or by land.

Likewise, Turkey views the U.S. vital to its own security, since it is surrounded by conflict, and within range of missiles being fired from Iran or Russia. The U.S. is also Turkey's biggest military arms supplier providing $80 \%$, despite recent efforts to diversify its dependence due to the S400 crisis. Large numbers of Turkish officers have been trained in the U.S., allowing armed forces to develop deep ties, which likewise supplies Turkey with knowledge of their operations and doctrine. By ousting of Turkey from the F-35 jet fighter strike program, she will swiftly be looking for alternatives in the near future. Equally noticeable is the fact that the U.S., including its EU allies, has backed Turkey against the PKK. The U.S has further continued to support Turkey's EU membership and advocated for the Caspian Baku-Tbilisi-Ceyan (BTC) oil pipeline.

Second, in order to overcome mutual historical mistrust and misunderstandings, both countries need to take measures for confidence-building. For that purpose, the two countries should agree on "equality and mutual respect for each other's interests - confidentiality and mutual trust - close and intensive consultations to identify common goals and strategies on issues of critical interest that will provide mutual benefits" (Albright, Hadley, 2012: 9-10). As Albright and Hadley assert, "Although a vibrant bilateral relationship already exists, there is an opportunity to institutionalize the relationship further and expand issues of common interest" (2012: 4).

Third, both parties need to avoid outcomes that further deteriorate the regional stability. Albright and Hadley suggest: improving their dialogue, build mutual trust, develop a common ground from which they can work more effectively together, identify a common post-Assad strategy, develop a transitional plan, coordinate the return of Syrian refugees, IDPs, and plans for post-war reconstruction (2012: 4-8). Turkey in this regard is critical to the U.S., not only as an important partner in the fight against radical groups such as ISIS and Al-Nusra, but also in providing strategic access to the İncirlik air base. Together, both can play a crucial role for stabilizing and reconstructing Syria after the war (Aydıntaşbaş, Kirişçi, 2017: 10).

Fourth, as previously mentioned, at the heart of the current U.S.-Turkey crisis is the Kurdish issue. This question needs to be resolved to be able to take steps forward and improve relations between the two allies. It is stressed by analysts that this is possible only if an agreement is reached between Turkey and the Kurds, both inside and 
outside of the country (Aydıntaşbaş, Kirişçi, 2017: 10). Abramowitz and Edelman also support the importance of Turkish-Kurdish cooperation in the revitalizing U.S.-Turkey relations (Abramowitz, Edelman, 2013: 28).

Fifth, Turkey and the U.S. have more than enough experiences, "resources, assets, and skills that will be complementary in helping various Arab countries achieve democratic transitions; ending the bloodshed in Syria through the departure of President Bashar al-Assad and the creation of a democratic, cross sectarian outcome" (Aydıntaşbaş, Kirişçi, 2017: 10). Liu and Taylor support the idea of strengthening mutual relations and converging interests (2016).

Sixth, both parties need to focus on regional stability and peace for controlling and/ or resolving refugee issues, preserving regional trade and energy security to ensure political, economic stability and democratic development.

In conclusion, Turkey and the U.S. have a deep and comprehensive political, diplomatic, economic and cultural relationship. They are allies in NATO and strategic partners. Throughout their historical partnership, they have had several crises, of which they have overcome in most cases. We assert that this current crisis is not necessarily any different. However, it is crucial that both parties prevent any further deterioration in their alliance, as it could have long term repercussions.

\section{REFERENCES}

Abramowitz M., Edelman E. S. (2013), U.S.-Turkey Cooperation Toward a Post-Assad Syria, National Security Program Foreign Policy Project.

Ahmad P. T. (2015), US-Turkey Relations and Syria Crisis, “Alternatives”, Vol 4, No. 4, http://alternatives.yalova.edu.tr/article/view/5000173351/5000164712 (21.08.2017).

Akyeşilmen N. (2014), Çatışa Yönetimi: Kavramsal ve Kuramsal Bir Analiz, in: Brışı Konuşmak: Teori ve Pratikte Çatışma Yönetimi (2. baskı), (ed.) Nezir Akyeşilmen, ODTÜ yayınevi, Ankara.

Akyeşilmen N., Tinker V. (2016), Conflict Analysis: Rights-Based Peace Model, in: The Possibilities of Peace in Syria: An Alternative Approach to Conflict Analysis, (eds.) Nezir Akyeşilmen, Önder a Afşar, Orion Yayınevi, Ankara.

Albright M. K., Hadley S. J. (2012), U.S.-Turkey Relations: A New Partnership, "Independent Task Force Report No. 69”, Council On Foreign Relations, https://www.cfr.org/sites/default/ files/ pdf/2012/05/TFR69_Turkey.pdf (25.08.2017).

Aljazeera (2016), Turkey's jarablus operation Scorecard, http://www.aljazeera.com/indepth/opinion/2016/09/turkey-jarablus-operation-scorecard-160901095251276.html (31.08.2017).

Aljazeera (2019a), Turkey: S-400 purchase "not a preference but a necessity, "New/Russia", (13.07.2019).

Aljazeera (2019b), Turkey-US centre on Syria safe zone 'fully operational, https://www.aljazeera. com/news/2019/08/turkey-centre-syria-safe-zone-fully-operational-190824182223857.html (25.08.2019).

Altunışık M. B. (2016), The Inflexibility of Turkey's Policy in Syria, "Mediterrranean Yearbook", http://www.iemed.org/observatori/arees-danalisi/arxius-adjunts/anuari/med.2016/IEMed_ MedYearbook_2016_keys_Turkey_Syrias_Policy_Benli_Altunisik.pdf (29.08.2017). 
Aydıntaşbaş A., Kirişçi K. (2017), The United States and Turkey: Friends, Enemies or only Interests, Washington, The Centre on The United States and Europe at Brookings, Turkey project Policy Paper Number 12, https://www.brookings.edu/wp-content/uploads/2017/04/aydintasbaskirisci_united-states-and-turkey.pdf (28.08.2017).

Ayhan V. (2011), Arap Baharının ABD-Türkiye İlişkilerine Etkisi, "Ortadoğu Analiz”, Vol. 3, No. 36, http://www.orsam.org.tr/files/OA/36/2veysel.pdf (29.08.2017).

Bağcı H. (2014), Önsöz Yerine: Çatışma Analizi, in: Brışı Konuşmak: Teori ve Pratikte Çatışma Yönetimi (2. baskl), (ed.) Nezir Akyeşilmen, ODTÜ yayınevi, Ankara.

Barkey H. J. (2016), Syria's Dark Shadow Over US-Turkey Relations, "Turkish Policy Quarterly", Vol. 14, No. 4, http://www.aljazeera.com/indepth/opinion/2016/09/turkey-jarablus-operation-scorecard-160901095251276.html.

Bennett N. (2015), Turkey and the United States: Friends or Foes?, "Journal of the Oxford Centre for the Study of Law \& Public Policy" 1(2).

Çağlar B. (2012), Türkiye’nin Suriye Politikast: Yeni Klasik-Realist Bir Bakış, “Ortadoğu Analiz”, Vol. 4, No. 47, http://www.orsam.org.tr/files/OA/47/4bariscaglar.pdf (21.08.2017).

Demir S. (2012), Irak ve Suriye Krizlerinin Karşılaştırmalı Analizi: Nedenler, gelişmeler, Sonuçlar ve türkiye Üzerine Etkileri, "Türk Dünyası İncelemeleri Dergisi: Journal of Turkish World Studies", XII (2).

Dinçer O. B., Kutay M. (2013), The Arab Spring: A Game Changer in Turkey-EU Relations?, "Perspectives on European Politics and Society", Vol. 14, No. 4.

Doster B. (2013), Ittifaklar, Türk Dış Politikası ve Suriye, "Ortadoğu Analiz", Vol. 5, No. 58, http:// www.orsam.org.tr/files/OA/58/7barisdoster.pdf (21.08.2017).

Hacaoglu S. (2019), Turkey Sees U.S. Deal as Start of Wider Purge of Kurdish Militia, https://www. bloomberg.com/news/articles/2019-08-24/turkey-sees-u-s-deal-as-start-of-wider-purge-ofkurdish-militia (12.09.2019).

Kırdar S. (2012), Türkiye-ABD İlişkilerinde politika Farklılıkları Derinleşirken, Ankara, TEPAV Değerlendirme Notu, http:/www.tepav.org.tr/upload/files/13561763991.Turkiye_ABD_Iliskilerinde_Politika_Farkliliklari_Derinlesirken.pdf (28.08.2017).

Lister T. (2019), Turkey bought Russian S-400 missiles designed to down NATO planes. For the US, that's a Problem, CNN, https://edition.cnn.com/2019/07/13/europe/turkey-russia-missilesnato-analysis-intl/index.html (21.08.2019).

Liu K., Taylor C. (2011), United States-Turkey-Iran: Strategic Options for the Coming Decade, Institute of Politics, http://iop.harvard.edu/sites/default/files_new/Programs/US_TurkeyIranPolicyPaper.pdf (31.08.2017).

HIIK (2003), Conflict Barometer 2003, Heidelberg Institute on International Conflict Research. https://hiik.de/download/conflict-barometer-2003/ (21.05.2020).

Pirinççi F. (2014), ABD'nin IŞID Stratejisi ve Irak ile Suriye 'ye Olası yansımaları, ORSAM Raport No. 191, Ankara.

Muasher M., Bubnova N. (2012), The Fall of Bashar-al Assad's Regime Is Inevitable, Carnegie Endowment for International Peace, https://carnegieendowment.org/2012/02/29/fall-of-basharal-assad-s-regime-is-inevitable-pub-47334 (25.08.2017).

Safeworld, Conflict Analysis, www.saferworld.org.uk/downloads/chapter2_266.pdf (10.12.2016).

Schanzer J., Tahiroglu M. (2016), Ankara's Failure: How Turkey Lost The Arab Spring, Foreign Affairs, https://www.foreignaffairs.com/articles/turkey/2016-01-25/ankaras-failure (21.05.2020).

Stein A. (2019), The Crisis Is Coming: Syria and the end of the U.S.-Turkish Alliance, War on The Rocks, https://warontherocks.com/2019/08/the-crisis-is-coming-syria-and-the-end-of-theu-s-turkish-alliance/ (13.08.2020). 
Tanır İ. (2011), How does the Arab Spring Transformed Turkish-American Relations, "Turkish Policy Quarterly", Vol. 10, No. 3, http://turkishpolicy.com/Files/ArticlePDF/how-the-arab-springis-transforming-turkish-american-relations-fall-2011-en.pdf (25.08.2017).

Tanış T. (2016), US-Turkey Relations at a Breaking Point over the Kurds, "Turkish Policy Quarterly", 14 (4), http://turkishpolicy.com/article/791/us-turkey-relations-at-a-breaking-pointover-the-kurds (09.08.2017).

TEPAV, Türkiye-Avrupa Birliği-ABD: İlişkiler Nereye?, TOBB Ekonomi ve Teknoloji Üniversitesi [n.a.], http://www.tepav.org.tr/upload/files/haber/1281443139-0.Iliskiler_Nereye_Gidiyor. pdf (31.08.2017).

Türkmen F. (2016), Obama Dış Politikasının Genel Değerlendirmesi ve Türkiye, "Bilgesam", http://www.bilgesam.org/Images/Dokumanlar/0-459-2016042559obama_sunum.pdf (24.08.2017).

Uslu N. (2000), 1947'den Günümüze Türk-Amerikan İlişkilerniin Genel Pırtresi, “Avrasya Dosyası”, Vol. 6, No. 2, http://21yyte.org/assets/uploads/files/203-232\%20nasuh\%20uslu.PDF (31.08.2017).

Yegin M., Selim H. (2016), U.S.-Turkey Relations: How to Proceed after Obama, "GMF On Turkey Series", https://ssrn.com/abstract=2873634 (31.08.2017).

Zanotti J. (2013), Turkey: Background and U.S. Relations in Brief, Washington, CRS Report Prepared for members and committee of Congress, April 2013, https://digital.library.unt.edu/ ark:/67531/metadc627098/m1/1/high_res_d/R44000_2015Apr23.pdf (29.08.2017).

\begin{abstract}
Turkey and the United States of America have been strategic partners for over seven decades. Nevertheless, their relationship has not always been a smooth one, and the two countries have encountered temporary bilateral crises from time to time. In spite of the challenges, over the years, the NATO allies - the United States and Turkey have continued to reaffirm their commitment to cooperate with each other as "strategic partners." However, the ensuing Syrian crisis has brought the relationship between the allies to an all-time historic low. This study examines Turkey-US relations in the context of the ongoing Syrian conflict using a conflict analysis framework. With this framework, we analyze the historical background, identify the root causes of the crisis and conduct an actor analysis. Based on our findings, we provide policy recommendations to de-escalate and transform the current crisis in US-Turkey relations in order to both restore their mutual trust and find new ways to cooperate as strategic partners.
\end{abstract}

Keywords: Turkey, US, Syria, civil war, conflict analysis, cooperation, confrontation

\title{
STOSUNKİ TURECKO-AMERYKAŃSKİE W KONTEKŚCİE KONFLİKTU W SYRIII: OD WSPÓŁPRACY DO KONFRONTACJI
}

\section{STRESZCZENIE}

Turcja i Stany Zjednoczone są partnerami strategicznymi od ponad siedemdziesięciu lat. Wzajemne stosunki nie zawsze przebiegały jednak bezkonfliktowo i sporadycznie dochodziło do przejściowych kryzysów dwustronnych. Mimo wyzwań, obaj sojusznicy z NATO - Stany Zjednoczone i Turcja - od lat potwierdzają swoje zaangażowanie we współpracę jako ,partne- 
rzy strategiczni”. Jednak wskutek narastającego kryzysu syryjskiego stosunki między sojusznikami osiągnęły bezprecedensowo niski poziom. Niniejsze studium analizuje stosunki między Turcją a Stanami Zjednoczonymi w kontekście trwającego w Syrii konfliktu z zastosowaniem metody analizy konfliktu. W jej ramach analizujemy tło historyczne, określamy pierwotne przyczyny kryzysu i przeprowadzamy analizę aktorów. Na podstawie swoich ustaleń przedstawiamy zalecenia dotyczące polityki mającej na celu de-eskalację i przekształcenie obecnego kryzysu w stosunkach USA-Turcja w sposób pozwalający przywrócić wzajemne zaufanie, ale także znaleźć nowe sposoby współpracy w charakterze strategicznych partnerów

Słowa kluczowe: Turcja, USA, Syria, wojna domowa, analiza konfliktów, współpraca, konfrontacja 